\title{
EHMTI-0107. Treatment of migraine in Croatia, year 2013
}

\author{
V Vukovic Cvetkovic ${ }^{1 *}$, S Zupanic ${ }^{2}$, M Podgornik $^{3}$ \\ From 4th European Headache and Migraine Trust International Congress: EHMTIC 2014 \\ Copenhagen, Denmark. 18-21 September 2014
}

\section{Aims}

To estimate the burden and current treatment patterns of migraine in Croatia.

\section{Methods}

This was a public health study conducted from April to June 2013. in Croatia. A questionnaire with 10 questiones was sent to 2750 E-mail addresses, randomly chosen from various internet sites.

\section{Results}

Of 2750 sent E mails, 246 declared having migraine; 209 $(85 \%)$ were women $(56.5 \%$ aged $18-45$ years; $28.7 \%$ aged 46-65 year; 37 (15\%) were men (8.1\% aged $18-45$ years and $6.5 \%$ aged $46-65$ years). Up to 2 attacks per month had $59.4 \%, 2-10$ attacks had $38.6 \%$ and $>10$ attacks had $2 \%$ of respondents. In the last 3 months, $74.4 \%$ was never absent from work because of headache, 20.7\% was absent $<2$ days and $4.9 \%$ was absent $>3$ days. Working with $50 \%$ reduced capacity declared $21.5 \%$ on $<2$ days, $24 \%$ on $3-4$ days and $21.6 \%$ on $>5$ days. In acute migraine attacks 71.5\% used NSAIDs and simple analgesics, 9.4\% triptans, $11.4 \%$ combination of drugs (NSAIDs + triptan) and 3.3\% ergotamins. Two drugs per attack takes $39.4 \%$, one drug $26.4 \%$ and $>3$ drugs $30.9 \%$. Only $9.4 \%$ respondents was completely satisfied with acute drug treatment, $75 \%$ efficacy declared $33.7 \%, 50 \%$ efficacy $32.1 \%$ and less than $25 \%$ efficacy declared 23.6\%. Prophylactic therapy (beta blockers, antidepressants or anticonvulsives) used 7.3\%; $11 \%$ used magnesium, vitamins or herbal drugs.
'Department of Neurology, Univesity Hospital Center "Sestre Milosrdnice", Zagreb, Croatia

Full list of author information is available at the end of the article

\section{Conclusion}

This study provides the most current available estimates of the impact and treatment patterns of migraine in Croatia. Migraine is under-treated and represents a major public health problem.

No conflict of interest.

\section{Authors' details}

${ }^{1}$ Department of Neurology, Univesity Hospital Center "Sestre Milosrdnice", Zagreb, Croatia. ${ }^{2}$ General Practice "Krunoslav Reljanovic", General Practice "Krunoslav Reljanovic", Zagreb, Croatia. ${ }^{3}$ University School of medicine

Zagreb, University School of Medicine Zagreb, Zagreb, Croatia.

Published: 18 September 2014

doi:10.1186/1129-2377-15-S1-G41

Cite this article as: Cvetkovic et al:: EHMTI-0107. Treatment of migraine in Croatia, year 2013. The Journal of Headache and Pain 2014 15(Suppl 1): G41.

\section{SpringerOpen $^{\odot}$}

(C) 2014 Cvetkovic et al; licensee Springer. This is an Open Access article distributed under the terms of the Creative Commons Attribution License (http://creativecommons.org/licenses/by/2.0), which permits unrestricted use, distribution, and reproduction in any medium, provided the original work is properly cited.
Submit your manuscript to a SpringerOpen ${ }^{\circ}$ journal and benefit from:

- Convenient online submission

- Rigorous peer review

- Immediate publication on acceptance

- Open access: articles freely available online

- High visibility within the field

Retaining the copyright to your article

Submit your next manuscript at $>$ springeropen.com 